\title{
DIAGNOSTICS AND INTENSIVE CARE OF HEART FAILURE IN PATIENTS WHO UNDERWENT CORONARY ARTERY BYPASS GRAFT SURGERY WITH ARTIFICIAL CIRCULATION
}

\section{I. Cherniy, Y. V. Kurylenko}

State Institution of Science «Research and Practical Center of Preventive and Clinical Medicine» State Administrative Department, Kyiv, Ukraine

\section{Summary}

Introduction. Coronary heart disease, the complexity of the surgery conducted, inflammatory reaction to extracorporeal circulation and the need for perioperative anticoagulation influence perioperative state of hemodynamics during the surgical revascularization of a myocardium in patients with coronary heart disease.

The aim. To improve the results of treatment of cardiac surgery patients with heart failure who underwent surgery, namely, coronary artery bypass grafting using extracorporeal circulation by improving methods of diagnosing heart failure.

Materials and methods. 100 cardiac surgery patients with coronary heart disease were operated on at State Institution of Science «Research and Practical Center of Preventive and Clinical Medicine» State Administrative Department. In all the cases, coronary artery bypass grafting was performed using artificial circulation. In patients of group 1 (40 patients) in the postoperative period, the correction of hemodynamic disorders was performed according to the standard protocol. In group 2 (60 patients) - a differentiated approach to the correction of hemodynamic disorders was used.

Results. It was found that in group 2 for stabilization of hemodynamics, oxygen status, microcirculation, smaller doses of sympathomimetics and shorter duration of their use, $\mathrm{P}<0.05$ than in 1 were applied.

Conclusions. The results of the studies indicate the possibility of using the method of phasography, in particular, the analysis of symmetry of the T wave, as a marker of ischemic changes in the myocardium in cardiac patients who underwent coronary artery bypass grafting using artificial circulation. The obtained data show that the developed algorithm of perioperative management of cardiac surgery patients with heart failure makes it possible to significantly accelerate the rehabilitation of cardiac surgery patients, increase patient comfort and reduce the length of their hospitalization. The possibility of using phasography for monitoring of myocardial condition in patients undergoing coronary artery bypass surgery has been investigated.

Keywords: CABG, perioperative management, differentiated approach, phasography

\section{INTRODUCTION}

Coronary heart disease, the complexity of the surgery conducted, inflammatory reaction to extracorporeal circulation and the need for perioperative anticoagulation influence perioperative state of hemodynamics during the surgical revascularization of a myocardium in patients with coronary heart disease [1].

Systemic inflammatory response (SIR), which occurs while artificial blood circulation (ABC) is being con- ducted, is connected to a number of specific factors which systematically influence the organism. They are: a surgical trauma, blood contact with the foreign surface of the artifical blood circulation machine, ischemic reperfusion injuries, hypothermia, hemodilution due to the use of solutions for cardioplegia and primary filling of the circuit of the artificial blood circulation machine [2]. Systemic inflammatory response syndrome causes changes in cardiac output, and delivery and consumption of oxygen. Coronary heart disease of the patient, the complexity of 
surgery, inflammatory reaction to extracorporeal circulation and the need for perioperative anticoagulation are the factors which influence the perioperative state of hemodynamics [2].

Induced cardiac arrest and the associated period of general ischemia is an obligatory stage in the process of extracorporeal circulation. This is why acute heart failure of this or that stage can occur when performing operations of aortocoronary bypass grafting in the conditions of artificial blood circulation. Despite the fact that the methods of artificial blood circulation are constantly getting improved, the frequency of intraoperative myocardial infarction occurs in 2 to $7,2 \%$ of cases, acute heart failure in 2,7 to $51,2 \%$ of cases, acute cardiac arrhythmias in from 20 to $63,6 \%$ of cases [3].

As a rule, patients usually need postoperative hemodynamic support for several hours after the cardiac surgery. They are sedated and are on prolonged mechanical ventilation in the intensive care unit (ICU) [3], and receive infusion therapy for a short period of time.

The aim. To improve the results of treatment of cardiac surgery patients with heart failure who underwent surgery, namely, coronary artery bypass grafting using extracorporeal circulation by improving methods of diagnosing heart failure.

Materials and methods. 100 cardiac surgery patients with coronary heart disease were operated on at State Institution of Science «Research and Practical Center of Preventive and Clinical Medicine» State Administrative Department. In all the cases, coronary artery bypass grafting was performed using artificial circulation. All patients gave informed consent to participate in the study. The patients were divided into two groups.

In patients of group 1 (40 patients) in the postoperative period, the correction of hemodynamic disorders was performed according to the standard protocol. In group 2 (60 patients) - a differentiated approach to the correction of hemodynamic disorders was used: for subgroup 1 (20 patients), the correction of hemodynamic disorders was performed with dobutamine and achieved stabilization in the postoperative period; for subgroup 2 (11 patients, in whom hypophosphatemia was diagnosed in the preoperative period) Fructose-1,6-diphosphate was used according to the scheme in addition to dobutamine, for the correction of hemodynamic disorders: 5 grams of the drug were injected immediately before the perfusion and 5 grams at the 30th minute of artificial circulation. The drug, endogenous high-energy intermediate metabolite of the glycolytic pathway, directly increases the formation of high-energy phosphate (ATP) [4]; for subgroup 3 (6 patients) Tivorel ( $1 \mathrm{ml}$ of solution contains $42 \mathrm{mg}$ of arginine hydrochloride and $20 \mathrm{mg}$ of levocarnitine) was used in the postoperative period besides dobutamine for the correction of hemodynamic disorders. Arginine has antihypoxic, membrane stabilizing, cytoprotective, antioxidant, antiradical, detoxifying effect and manifests itself as an active regulator of energy supply processes. Levocarnitine is required for the transport of long-chain fatty acids in the mitochondria for their subsequent beta-oxidation and the formation of energy in the myocardium [5]. Subgroup 4 (23 patients) did not have hemodynamic disorders in the postoperative period so the correction was not performed.

ECG, echocardiography, heart rate variability according to R. M. Baevsky, phasography were used to monitor the function of the cardiovascular system. The parametres of phasography and heart rate variability were measured: 1 - before the surgery, 2 - after the patient was taken to the intensive care unit, 3 - after the patient's condition had stabilized (stabilization of hemodynamics and respiration). The following frequency indicators of the heart rate variability were analysed: LF (Mc2) - low frequency (LF). It characterizes the effect of the sympathetic ANS on heart rate, in particular, the activity of the vasomotor center of the medulla oblongata and baroreflexes. HF (Mc2) - high frequency $(\mathrm{HF})$. It corresponds to the indicator of vagal activity. LF / HF reflect the sympathetic-vagal balance.

Phasography is an innovative method of electrocardiogram (ECG) processing, developed by the NAS of Ukraine [6]. The essence of the method is the study of symmetry-asymmetry of the $\mathrm{T}$ wave of the electrocardiogram as a marker of ischemic changes in the myocardium [6]. Determination of the symmetry of the $T$ wave in the phase space is an effective diagnostic criterion for the presence of ischemia ( $\beta$ T index) on the electrocardiogram. The main feature of phasography is the transition from the scalar ECG signal $z(t)$ in any of the leads to its reflection on the phase plane with coordinates $\mathrm{z}(\mathrm{t}), \dot{\mathrm{z}}(\mathrm{t})$, where $\dot{z}(\mathrm{t})$ stands for the signal change rate. Depending on the value of $\beta$ T was divided into three groups: the first group - «healthy» with an indicator $\beta$ T up to 0,7 ; the second group - «borderline condition or pre-disease group» ( $\beta$ T in the range $0,7-1,05)$; the third group - «pathology» ( $\beta$ T higher than 1,05$)[6]$.

Preoperative assessment of myocardial reserves was performed using the NYHA classification of coronary heart disease and respiratory failure by grades 1 to 4 according to the NYHA classification. Physical examination aims to determine the degree of left and right ventricular failure, and symptoms of acute arrhythmia. The left ventricular ejection fraction (LVEF) is determined. If it is less than $50 \%$, it is defined as systolic dysfunction; if it is more than $50 \%$, it is diastole dysfunction.

Inclusion criteria. The study included patients with coronary heart disease with chronic heart failure who were scheduled for cardiac surgery using artificial circulation.

Non-inclusion criteria. A hereditary fructose intolerance, creatinine clearance below $50 \mathrm{ml} / \mathrm{min}$., hypernatremia, hyperphosphatemia, a history of allergic reactions to drugs used in artificial circulation (ABC), disagreement of the patient to participate in the research. 
MedStat was used to analyze the results. Comparison criteria for related samples were used in the analysis. The critical significance level is 0.05 .

These survey methods were approved by the ethics committee of «Research and Practical Center of Preventive and Clinical Medicine»

Results. Changes in the parameters of variation pulsometry at the stages of the study indicate the minimal severity of the autonomic response to surgical stress when using the protocol of perioperative management of patients. Thus, at stage 1 (before surgery), stage 2 (after transfer to
ICU), stage 3 (after stabilization of the patient), the ratio of LF / HF in patients was respectively: $\mathrm{Me}( \pm$ CI 95\%) $=$ $1.27(0,55-1.66), \mathrm{Me}( \pm$ CI 95\%) $=1.17(0.83-1.44)$, $\operatorname{Me}( \pm$ CI 95\% $)=1.09(0.43-3.36)$.

Indicators of variation pulsometry at stage 1 of the study significantly $(\mathrm{P}<0,05)$ differed from the control group. However, the confidence interval in the second period of the study (after surgery) was the smallest, not significantly different from that in the control group. This indicates the absence of sympathetic irritation during anesthesia (Fig. 1).

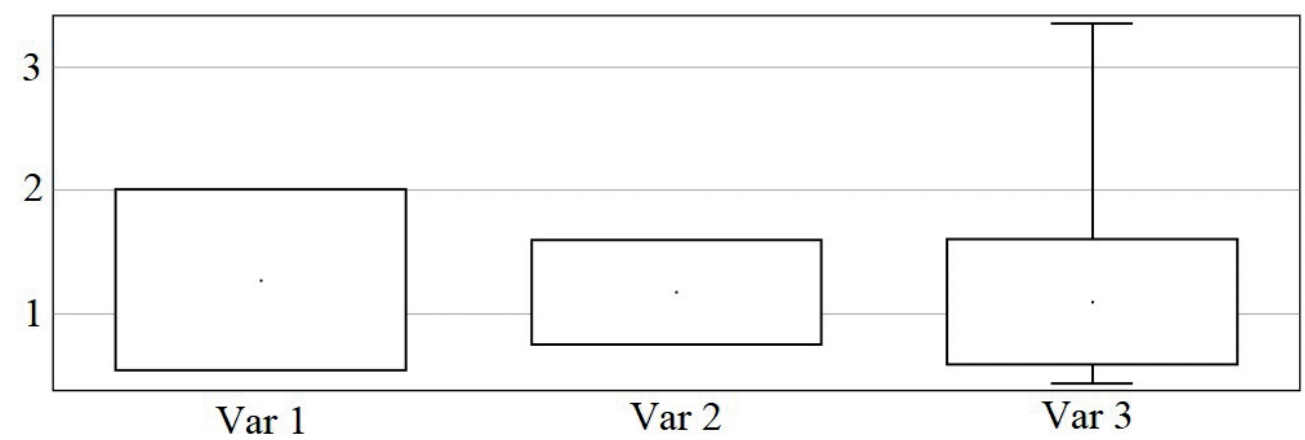

Fig. 1. The ratio of LF / HF in cardiac patients who underwent coronary artery bypass grafting using artificial circulation at the study stages (Var 1, Var 2, Var 3)

The possibilities of phasography in the analysis of ECG of patients who underwent coronary artery bypass surgery for the diagnostics of myocardial ischemia by assessing the phase of repolarization were investigated. Statistically, the vast majority of patients with coronary heart disease had the symmetry of the $T$ wave significantly higher than individuals without clinical signs of ischemic changes in the myocardium had and was $\mathrm{Me}( \pm \mathrm{CI} 95 \%)=1.57$ (0.95-1.96), $\mathrm{P}<0.05)$.

Patients of group 1 in the postoperative period correction of hemodynamic disorders were performed according to the standard current protocol. The indicator of phazog- raphies of the dynamics of treatment was: before surgery $-\beta \mathrm{T}=\mathrm{Me}( \pm \mathrm{CI} 95 \%)=0.7475(0.498-0.903)$, after surgery $-\beta \mathrm{T}=\mathrm{Me}( \pm \mathrm{CI} 95 \%)=0.726(-0.196-1.03)$, after stabilization of hemodynamics $-\beta \mathrm{T}=\mathrm{Me}( \pm \mathrm{CI} 95 \%)=$ $0,7685(-0,314-1,44)$. Thus, statistically, the indicators of phazography in the dynamics of the study remained in the «borderline» state, and did not change significantly. However, the confidence interval in the third period of the study was the largest, significantly different from the control group in the first and second periods. This indicates a large discrepancy in the index of phase in the third period (Fig. 2).

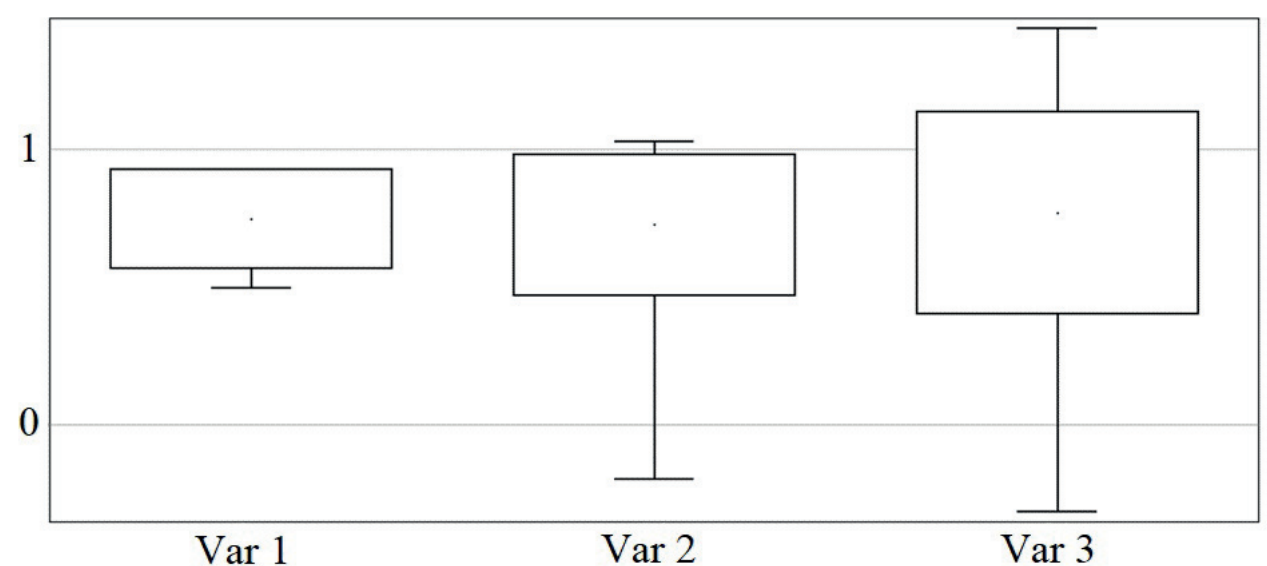

Fig.2. Indicators of phasography in patients of group 1 at the stages of the study (Var1, Var2, Var3) 
Patients in group 2 (subgroup 4) in the postoperative period did not have hemodynamic disorders, and the correction was not performed. The phase index in patients without heart failure before surgery was: $\beta \mathrm{T}=$ $\mathrm{M}( \pm \mathrm{CI} 95 \%)=0.88(0.75-1.01) \mathrm{SD}( \pm \mathrm{CI} 95 \%)=0.062$ (0.03-0.09); after the operation $-\beta \mathrm{T}-\mathrm{M}( \pm \mathrm{CI} 95 \%)=$ $0.81(0.68-1.07) \mathrm{SD}( \pm$ CI 95\%) $=0.02(0.02-0.03)$. Thus, the indicators of phazography in the dynamics of the study statistically remained in the «borderline state», and did not change significantly.

In group 2, where a differentiated approach to the correction of hemodynamic disorders was used (subgroup 1, subgroup 2 and subgroup 3), in the postoperative period, the correction of hemodynamic disorders was performed using dobutamine and tyvorel. The phase index in patients with heart failure before surgery was: $\beta \mathrm{T}=\mathrm{M}( \pm \mathrm{CI} 95 \%)=0.7685(-0.401-2.04) \mathrm{SD}$ $( \pm$ DI $95 \%)=0.0442(0.006-0.25)$; after surgery $-\beta \mathrm{T}-$ $\mathrm{M}( \pm \mathrm{CI} 95 \%)=0,588(-0,35-0,847) \mathrm{SD}( \pm$ CI 95\% $)=$ 0,024 (0,0106-0,098; after stabilization of hemodynam$\mathrm{ics}-\beta \mathrm{T}=\mathrm{Me}( \pm \mathrm{CI} 95 \%))=0.2405(-0.56-0.93) \mathrm{SD}$ $( \pm$ CI 95\% $)=0.017(0.003-0.045)$ Thus, the indicators of phazography in the dynamics of the study were transformed from the zone of «pathology» and «borderline state» to the zone of normal indicators.

It was found that in group 2 for stabilization of hemodynamics, oxygen status, microcirculation, smaller doses of sympathomimetics and shorter duration of their use, lower frequency of hemodynamically significant atrial fibrillation, dose of amiodarone, shorter duration of artificial ventilation $\mathrm{P}<0.05$ than in 1 were applied.

Conclusions. 1. The results of the studies indicate the possibility of using the method of phasography, in particu- lar, the analysis of symmetry of the $\mathrm{T}$ wave, as a marker of ischemic changes in the myocardium in cardiac patients who underwent coronary artery bypass grafting using artificial circulation.

2. The obtained data show that the developed algorithm of perioperative management of cardiac surgery patients with heart failure makes it possible to significantly accelerate the rehabilitation of cardiac surgery patients, increase patient comfort and reduce the length of their hospitalization.

3. The possibility of using phasography for monitoring of myocardial condition in patients undergoing coronary artery bypass surgery has been investigated.

Conflict of interest. The authors declare no conflict of interest.

Financing. The study was performed as part of research work «Optimization of specialized and highly specialized medical care of surgical profile on the principles of «Fast track surgery» for certain diseases of the thyroid and thyroid glands, internal and reproductive organs, abdominal wall, in particular using atomic force microscopy and using the method of prelamination for processing.

Observance of ethical norms. In conducting the study, the authors adhered to the principles of the Declaration of Helsinki, the Council of Europe Convention on Human Rights and Biomedicine (1997), the relevant provisions of the WHO, the International Council of Medical Research Societies, the International Code of Medical Ethics (1983) and the laws of Ukraine. Each patient included in the study signed an informed consent for medical intervention. The study protocol was approved by the local ethics commission.

\section{ЛITEPATУРA}

1. Fluid management in patients undergoing cardiac surgery: effects of an acetate versus lactate buffered balanced infusion solutionon hemodynamic stability / Pfortmueller C. A. et al. CriticalCare. 2019. 23. P. 159.

2. Бабаев М. А., Еременко А. А., Минболатова Н. М., Дземешкевич С. Л. Синдром полиорганной недостаточности у больных после операций в условиях искусственного кровообращения. Хирургия. Журнал им. Н. И. Пирогова. 2013. 2. С. 119-123.

3. Loskutov O. A., Druzhyna O. M., Dzyuba D. O., Pashchenko S. V. Comparison of cardioprotective properties of artificial electrical fibrillation of the heart and Bretschneider solution during coronary artery bypass grafting. Emergency Medicine. 2019. 2 (97). P. 105-110.

4. Myocardial protection using fructose-1,6-diphosphate during coronary artery bypass graft surgery: a randomized, placebo-controlled clinical trial / Riedel B. J. et al. AnesthAnalg. 2004. 98. P. 20-9.

5. Олейников Д. А., Яшин А. В. Энергетический обмен миокарда в норме и при патологии. РВЖ МДЖ. 2015. 5. С. 38-41.

6. Скрининг ишемии миокарда методом оценки фазы реполяризации / Дячук Д. Д., та ін. Український кардіологічний журнал. 2016. 6. С. 82-89. 


\section{REFERENCES}

1. Pfortmueller, C. A., Faeh, L., Müller, M., Eberle, B., Jenni, H., Zante, B., Prazak, J., Englberger, L., Takala, J., \& Jakob, S. M. (2019). Fluid management in patients undergoing cardiac surgery: effects of an acetate- versus lactate-buffered balanced infusion solution on hemodynamic stability (HEMACETAT). Critical care (London, England), 23(1), 159. https://doi. org/10.1186/s13054-019-2423-8

2. Babaev, M A, Eremenko, A A, Minbolatova, N M, Dzemeshkevich, S L. (2013). Sindrom poliorgannoj nedostatochnosti u bolnyh posle operacij v uslovajah iskusstvennogo krovoobraschenia [The multiple organ failure syndrome after cardiac surgery with artificial blood circulation]. Khirurgiya, 2,119-123. https://doi. org/10.15360/1813-9779-2010-3-76

3. Loskutov, O.A., Druzhyna, O.M., Dzyuba, D.O., Pashchenko, S.V. (2019). Comparison of cardioprotective properties of artificial electrical fibrillation of the heart and Bretschneider solution during coronary artery bypass grafting. Emergency Medicine, 2 (97), 105-110. https://doi.org/10.22141/2224-0586. 2.97.2019.161648
4. Riedel, B. J., Gal, J., Ellis, G., Marangos, P. J., Fox, A. W., \& Royston, D. (2004). Myocardial protection using fructose-1,6-diphosphate during coronary artery bypass graft surgery: a randomized, placebo-controlled clinical trial. Anesthesia and analgesia, 98(1), 20-29. https://doi.org/10.1213/01.ANE.0000094336.97693.90

5. Oleynikov, D.A., Yashin, A.V. (2015). Energeticheskij obmen miokarda v norme i pri patologii [Normal and pathological energy metabolism of the myocardium]. RVZh - MDZh, 5, 38-41. http://cyberleninka. $\mathrm{ru} /$ article/n/energeticheskiy-obmen-miokarda-vnorme-i-pri-patologii

6. Dyachuk, D.D., Kravchenko, A.N., Feinzilberg, L.S., Stanislavskaya, S.S., Korchinskaya, Z.A, Orikhovskaya, K.B., Pasko, V.S., Mikhalev, K.A. (2016). Skrining ishemii miokarda metodom ocenki fazy repolarizacii [Screening of myocardial ischemia by the method of estimating the repolarization phase]. Ukrainskij kardiologichnyj zhurnal, 6, 82-89. http://nbuv.gov.ua/ UJRN/Ukzh_2016_6_11

\section{Резюме}

\section{ДІАГНОСТИКА ТА ІНТЕНСИВНА ТЕРАПІЯ СЕРЦЕВОЇ НЕДОСТАТНОСТІ У ПАЦІЄНТІВ, ЩО ПЕРЕНЕСЛИ ШУНТУВАННЯ КОРОНАРНОЇ АРТЕРІЇ З ВИКОРИСТАННЯМ ШТУЧНОГО КРОВООБІГУ}

\section{В. І. Чорній, І. В. Куриленко}

Державна наукова установа «Науково-практичний центр профілактичної та клінічної медицини» Державного управління справами, м.Київ, Україна

Вступ. Ішемічна хвороба серця, складність проведеної операції, запальна реакція на екстракорпоральний кровообіг та необхідність періопераційної антикоагулянтної терапії впливають на періопераційний стан гемодинаміки під час хірургічної реваскуляризації міокарда у хворих на IXC.

Мета дослідження. Поліпшити результати лікування кардіохірургічних хворих із серцевою недостатністю, які перенесли операцію, а саме аортокоронарне шунтування з використанням екстракорпорального кровообігу, шляхом удосконалення методів діагностики серцевої недостатності.

Матеріали та методи. У АНУ «Науково-практичний центр профілактичної та клінічної медицини» АУС прооперовано 100 хворих на ішемічну хворобу серця. У всіх випадках аортокоронарне шунтування проводилося за допомогою штучного кровообігу. У пацієнтів 1 групи (40 хворих) у післяопераційному періоді корекцію гемодинамічних розладів проводили за стандартним протоколом. У 2 групі (60 пацієнтів) - застосовувався диференційований підхід до корекції гемодинамічних порушень.

Результати. Встановлено, що у групі 2 для стабілізації гемодинаміки, кисневого статусу та мікроциркуляції застосовували менші дози симпатоміметиків, фіксували меншу тривалість їх застосування, ніж у групі 1 . Висновки. Результати досліджень свідчать про можливість використання методу фазаграфії, зокрема аналізу симетрії зубця Т, як маркера ішемічних змін міокарда у кардіологічних хворих, яким було виконано аортокоронарне шунтування з використанням штучного кровообігу. Отримані дані свідчать, що розроблений алгоритм періопераційного ведення кардіохірургічних хворих із серцевою недостатністю дає змогу значно прискорити реабілітацію кардіохірургічних хворих, підвищити комфорт пацієнтів та скоротити тривалість їх госпіталізації. Аосліджено можливість використання фазаграфії для моніторингу стану міокарда у пацієнтів, які перенесли аортокоронарне шунтування.

Ключові слова: АКШ, периопераційне ведення, диференційований підхід, фазаграфія 


\title{
Резюме
}

\section{ДИАГНОСТИКА И ИНТЕНСИВНАЯ ТЕРАПИЯ СЕРДЕЧНОЙ НЕДОСТАТОЧНОСТИ У ПАЦИЕНТОВ, ПЕРЕНЕСШИХ ШУНТИРОВАНИЕ КОРОНАРНОЙ АРТЕРИИ С ИСПОЛЬЗОВАНИЕМ ИСКУССТВЕННОГО КРОВООБРАЩЕНИЯ}

\author{
В. И. Черний, Ю. В. Куриленко
}

Государственное научное учреждение «Научно-практический центр профилактической и клинической медицины» Государственного управления делами, г. Киев, Украина

Вступление. Ишемическая болезнь сердца, сложность проведенной операции, воспалительная реакция на экстракорпоральное кровообращение и необходимость периоперационной антикоагулянтной терапии влияют на периоперационное состояние гемодинамики во время хирургической реваскуляризации миокарда у больных ИБС.

Цель исследования. Улучшить результаты лечения кардиохирургических больных с сердечной недостаточностью, перенесших операцию, а именно аортокоронарное шунтирование с использованием экстракорпорального кровообращения, путем усовершенствования методов диагностики сердечной недостаточности.

Материалы и методы. В АНУ «Научно-практический центр профилактической и клинической медицины» ГУА было прооперировано 100 больных с ишемической болезнью сердца. Во всех случаях аортокоронарное шунтирование производилось с помощью искусственного кровообращения. У пациентов 1 группы (40 больных) в послеоперационном периоде коррекцию гемодинамических расстройств проводили по стандартному протоколу. Во 2 группе (60 пациентов) применялся дифференцированный подход к коррекции гемодинамических нарушений.

Результаты. Установлено, что в группе 2 для стабилизации гемодинамики, кислородного статуса и микроциркуляции применяли меньшие дозы симпатомиметики, фиксировали меньшую продолжительность их применения, чем в группе 1.

Выводы. Результаты исследований свидетельствуют о возможности использования метода фазаграфии, в частности, анализа симметрии зубца Т, как маркера ишемических изменений миокарда у кардиологических больных, которым было выполнено аортокоронарное шунтирование с использованием искусственного кровообращения. Полученные данные свидетельствуют, что разработанный алгоритм периоперационного ведения кардиохирургических больных с сердечной недостаточностью позволяет значительно ускорить реабилитацию кардиохирургических больных, повысить комфорт пациентов и сократить продолжительность их госпитализации. Исследована возможность использования фазаграфии для мониторинга состояния миокарда у пациентов, перенесших аортокоронарное шунтирование.

Ключевые слова: АКШ, периоперационное ведение, дифференцированный подход, фазаграфия.

Інформація про авторів знаходиться на сайті http://www.cp-medical.com.

Дата надходження до редакиї - 19.10.2021 p. 